\title{
The Effect of Cambridge Analytica Case in Cyberspace Politics
}

\author{
Dewi Masruroh ${ }^{1}$, Randhi Satria, S.I.P, MA ${ }^{2}$ \\ ${ }^{1}$ Student of International Relations Department of Universitas Sebelas Maret \\ ${ }^{2}$ Lecturer of International Relations Department of Universitas Sebelas Maret \\ Corresponding Author: Dewi Masruroh, Universitas Sebelas Maret, ddewi.msrh@gmail.com \\ Randhi Satria, Universitas Sebelas Maret, ransatria@staff.uns.ac.id
}

Keywords: Cambridge Analytica, Cyberspace Politics, Democracy, Freedom of Expression

\begin{abstract}
The Cambridge Analytica Cases with Facebook is already widening in worldwide since March 2018. This case became one of the mistakes in the political world, where the campaign process took unhealthy because it uses personal data in social media as an illegal analysis material. The case of Cambridge Analytica is important for an immediate response as this is a threat to the continued of cyberspace politics. Cyberspace politics should be held as a healthy, fast, and fair. In this case, the cyberspace politics found more challenges in the future because it affects the freedom of expression, unsecured to use social media and etcetera. To analyze this paper, the authors use the descriptive qualitative method to describe the case and process analysis. Furthermore, the authors hope this paper can be a trigger for further analysis and could be a reference for the study of cyberspace politics and Cambridge Analytica or other similar cases in the future.
\end{abstract}

\section{INTRODUCTION}

The case of Cambridge Analytica (CA) was first spread by one of CA's former workers Christopher Wylie. Wylie conveyed the CA's first secret to 'The Guardian', a media in the UK. Wylie says that CA uses the 'This is your digital life' application on Facebook that developed by Alexander Kogan, an application developer also called Dr.Spectre (The Guardian, 2018).

Kogan offers this app for Donald Trump's campaign strategy because the original application of CA that was made by Wylie and friends has many bugs and not developed correctly, said Ted Cruz, head of the Trump campaign. (Business causal, 2018). CA finally agreed to use Kogandeveloped applications. This application will analyze the psychology of Facebook users by connecting the application with Facebook, then CA could get the facebook user's personal data and their friends. After this application is used for a period of 3-5 months, CA could get approximately five million data (The Guardian, 2018).

This data is used by the CA to provide the right advertisement on the Facebook user page. CA itself has many divisions to succeed in its performance. The analytics division will divide the
Facebook user character, the creative team will determine the exact news and advertisements that will be presented on the Facebook user account, the IT section will bring up ads that have been created by the creative team on the Facebook user account (The Verge, 2018). By this strategy finally, Donald Trump won the US Presidential election of 2016.

\section{METHODS}

The qualitative descriptive method is chosen to analyze this paper and convey the facts clearly, thoroughly, and completely. The data that the authors will convey in this paper will be descriptive data which includes the Cambridge Analytica incident sequence and the presentation of the concept of cyberspace politics. To analyze this CA case, the authors use the theory of cyberspace politics concept from David Resnick.

Resnick explains in his article that the Internet that was originally only as a state personal communication or person-to-person has now turned into a very plural and even looks like a 
productive job. He divides the cyberspace politics into 3 types:

The first one is politic within the internet or intra-Net politics. Resnick thinks that people doing everything on the internet and politics on the internet becomes more organized because it is based on interests and profit. The second is politic that affect the net. It explains that a large number of internet users caused the government to provide new legal rules, and try to get profit from the internet also use the internet as a tool of government. The third is political uses of the net explain that the use of the Internet influence offline political activity.

From the theory above, it can be seen that the case of Cambridge Analytica is an old pattern of crime on the internet that has just been blowing up lately and making the discussion about internet crime become strained.

\section{RESULT AND DISCUSSION}

\subsection{Breaking the Law}

The conditions described above is a violation of human rights in running one of the privilege of cyberspace politics, that is freedom of expression. Cambridge Analytica has violated the law of free speech on the internet namely article 19 of the Universal Declaration of Human Rights.

"Everyone has the right to
freedom of opinion and
expression; this right includes
freedom to hold opinions
without any interference and
get through any media and
regardless of frontiers."

This article explains that humans still have the right to freedom of expression on the media. This freedom of expression includes the freedom to voice his political ideology in social media, freedom to comment, like the status, create status in social media and others. The freedom of speech must also be followed by the participation of the government in protecting its people, that the people expressing their opinions should not be imprisoned and should not misuse the aspirations of the people for the benefit of a particular group.

In addition to violating the rules of the Universal Declaration of Human Rights, this case also violates the Article 17 of Human Rights
Committee Comment No. 16 on the 'Rights to Respect of Privacy, Family, Home, and Correspondence, and Protection of Honor and Reputation'. It demonstrates the protection of individual privacy data. Moreover, it also violates the Council of Europe Convention on the Protection of Individuals with regard to Automatic Processing of Personal Data, the Flows of Personal Data, and the Guidelines for the regulation of computerized personal data files (General Assembly resolution, 1990)

\subsection{Making people afraid to express or speak in social media}

The CA case that already mentioned above, if left over by the law, it will harm to social media users or netizens in expressing their opinions freely on the internet or in social media. People will tend to be afraid of when they want to express their opinions on social media. This fear is groundless because they fear their data will be used by certain parties for their benefit. Based on CA cases, the data is only used by certain parties i.e the opposition, therefore, it is unilaterally profitable. But if their data is used for the development as the sake of the country, then it is good because of the cyberspace politics purposes. The point is the netizen private data should not be taken arbitrarily for the benefit of only part of the class.

\subsection{Limit political votes and weaken people's participation in a democratic country}

Cyberspace politics initially aims to make democracy better by making people more understanding about government politics. Therefore in that time, the country has a website on the internet to communicate with the people. Formerly, the internet develops and making social media presence easier for the government to socialize politics, because the government will be able to make a complaint application, or just as simple as creating an account in social media and the community can follow the account with the aim of it.

Then it can track the political development in the country and able to convey his opinion through comment field. The relationship between the government and the people until now is still on the positive side, because the people can make an easy complaint and the country understands the criticism of their policy implements. Within this 
method, democracy atmosphere in a country will be good. But when the comments, political status and political aspirations of people on the internet is used for the benefit of a group without permission, then this will have the opposite effect. Since social-media rules say that data holders and data tracers are only allowed by agencies that have been trusted by the government, when the data is hacked by a non-governmental agency then it should be criminalized.

If the incidence of Cambridge Analytica happens continuously, it will result in people's fear of expressing his political opinion on the internet. People fears in expressing their expression on the internet will affect the declining level of political participation of the public on the internet. Then, the ideals use of political cyberspace to strengthen the role of the people will be decline. This is in line with the basic principles of democracy i.e 'from the people, to the people, and by the people' it also seems dormant, because the role of the people here is reduced.Besides that, the case of Cambridge Analytica can also be detrimental to the politicians who will nominate themselves to the seat of government because of rise of fake account in Facebook. The rise of fake account in Facebook could be caused by political opposition. This things will lead confusion when prospective politicians convey their vision and mision in front of public. Is this really the desire of the people delivered on Facebook? Greene,R (1998) in his books The Laws of Powers said that a politicians must play what people needs to believe. So if the prospective politicians are not selective in using Cambridge Analytica data, it is likely that it can harm prospective politicians and threaten him in public voting laters.

\section{CONCLUSION}

In conclusion, the case of Cambridge Analytica should not be considered as an unimportant issue. Because if it keeps going on and is not taken seriously, then the political atmosphere becomes dirty and making people afraid to voice their political ideology in social media which will also have an effect on the declining level of public participation in democratic governance. This will make the shrinkage of democratic tension. It will also cause an effect into politicians when they are not selective enought using Cambridge Analytica data. It may cause chaos to their voters when the prospective politicians are not focus on distinguishing between real data and fake data. In the end, the incidence of Cambridge Analytica can provide effects like two sides of knife, it can effects peoples and it can also effect prospective politicians.The Cambridge Analytica incident was also proven injure human rights. It is violating the rules of mny Human Rights such as in the 'Rights to Respect of Privacy, Family, Home, Correspondence, and Protections of Honor and Reputations', 'Council of Europe Convention', on the Protection of Individuals with regard to Automatic Processing of Personal Data, the Flows of Personal Data, and the Guidelines for the regulation of computerized personal data files. The case of Cambridge Analytica may also lead another cases which has not been exposed. There are still many other social media that can be targeted by one agencies that resemble to Cambridge Analytica. Others social media like Twitter, Path, Instagram, LINE, and more it is more popular than Facebook. Does not rule out the possibility that later this things can be done on other social media.

\section{REFERENCE}

Dewi, Sinta. Konsep Perlindungan Hukum atas Privasi dan Data Pribadi Dikaitkan dengan Penggunaan Cloud Computing di Indonesia. Jurnal Yusticia: Vol.5 No.1 Januari - April 2016 Pg.22-30

Business Causal. The Man Behind Cambridge Analytica. $\begin{array}{llll}\text { Retrieved } & 19 & \text { May } & 2018\end{array}$ (https://www.youtube.com/watch?v=LuZmWvhtwa $\mathrm{E} \& \mathrm{t}=8 \mathrm{~s})$

Greene, R., \& Elfffers, J. (1998). The 48 Laws of Power.

Margolis, Michael and David Resnick. 2000. Politics as Usual: The Cyberspace 'Revolution'. London. Sage Publication

The Guardian. Cambridge Analytica whistleblower: 'We spent $\$ 1 \mathrm{~m}$ harvesting millions of Facebook. $\begin{array}{llll}\text { Retrieved } & 22 & \text { May } & 2018\end{array}$ (profiles'https://www.youtube.com/watch? $\mathrm{v}=\mathrm{FXdYS}$ Q6nu-M\&t=2s)

The Verge. Facebook's Cambridge Analytica data scandal, explained. Retrieved 24 may 2018 (https://www.youtube.com/watch?v=VDR8qGmyEQ $\mathrm{g} \& \mathrm{t}=218 \mathrm{~s})$

Scanlon, Thomas. A Theory of Freedom of Expression. Philosophy and Public Affairs. Vol.1, No.2, pp. 204226

Ulber Silalahi. 2009. Metode Penelitian Sosial, Bandung. Refika Aditama 
United Nations High Commisioner of Human Rights. General Comment No.16. Retrieved 24 May 2018 (ccprcentre.org/page/view/general_comments/27798 )

Universal Declaration of Human Rights, Article 19 